\title{
トキシコキネティクス/トキシコプロテオミクスによるナノマテリアルの安全性評価
}

\author{
鍋師裕美, ${ }^{a, b}$ 吉川友章, ${ }^{a, b}$ 今澤孝喜, ${ }^{b}$ 角田慎一, ${ }^{a, b, c}$ 堤 $\quad$ 康央 $*, a, b, c$
}

\section{Safety Assessment of Nanomaterials Using Toxicokinetics and Toxicoproteome Analysis}

\author{
Hiromi NABESHI ${ }^{a, b}$ Tomoaki YoSHIKAWA, ${ }^{a, b}$ Takayoshi IMAZAWA, ${ }^{b}$ \\ Shin-ichi TsUNODA, ${ }^{a, b, c}$ and Yasuo TSUTSUMI ${ }^{*, a, b, c}$ \\ ${ }^{a}$ Graduate School of Pharmaceutical Sciences, Osaka University, 1-6 Yamadaoka, Suita, Osaka 565-0871, \\ Japan, ${ }^{b}$ National Institute of Biomedical Innovation, 7-6-8 Saito-Asagi, Ibaraki, Osaka 567-0085, \\ Japan, and ${ }^{c}$ The Center for Advanced Medical Engineering and Informatics, \\ Osaka University, 2-2 Yamadaoka, Suita, Osaka 565-0871, Japan
}

(Received August 31, 2009)

\begin{abstract}
With recent development of the nanotechnology, nanomaterials have been successfully employed in various industrial applications such as medicine and cosmetics. Nanomaterials show the useful properties such as electronic reactivity and the tissue permeability that were not provided by micromaterials. Thus, nanomaterials are expected as innovative materials for the development of medicine and cosmetics. However, these innovative properties may show unknown biological responses that could not been detected by the conventional toxicity assay. For industrial development and affluent society establishment that enjoyed only a benefit of nanomaterials, it is urgent to gather information of the properties and the biological effects, and to establish the standard safety evaluation method of nanomaterials. So, we are analyzing association among property, biodistribution and biological effects of nanomaterials to search for the safety biomarker (functional-, molecular- and biochemical-biomarker) using nanosilicas (nSP) as a standard nanomaterial. Because nSP shows high uniform dispersibility and is already used in medicine, cosmetics and food additive, the results of this study are useful to extrapolate it to other nanomaterials and to make practicable as safety biomarker. In this report, we show the latest knowledge about the linkage information among property, biodistribution and biological effects of nSP by toxicokinetics and toxicoproteomics, and the search study of safety biomarker based on these basic information.
\end{abstract}

Key words——nanomaterial; toxicokinetics; toxicoproteomics; biomarker; nanosilica

\section{1.はじめに}

2000 年 1 月に当時の米国大統領クリントンが, 国家ナノテクノロジー戦略（National Nanotechnology Initiative）を宣言し，ナノテクノロジー産 業の開発を推進するために大規模な国家予算の投資 を開始した。これが起爆剤となって，例えばカーボ ンナノチューブやフラーレンといった新たなナノマ テリアルの開発や，ナノマテリアルを利用した製品 開発が世界的に進展することとなった。このような 世界的背景を受けてナノマテリアル産業の世界市場

${ }^{a}$ 大阪大学大学院薬学研究科 (T 565-0871 大阪府吹田 市山田丘 1-6), b独立行政法人医薬基盤研究所（二567 -0085 大阪府茨木市彩都あさぎ 7-6-8), c大阪大学臨床 医工学融合研究教育センター（广565-0871 大阪府吹田 市山田丘 2-2)

*e-mail: ytsutsumi@phs.osaka-u.ac.jp 本総説は, 日本薬学会第 129 年会シンポジウム GS6 で 発表したものを中心に記述したものである.
は, 20 年後には年 1 兆ドルにも達すると予想され ており,1)ナノマテリアル産業は，今後の世界経済 を牽引し，人類に多大な恩恵をもたらす 21 世紀の コア産業となるものと期待されている.

数あるナノマテリアルの中でもナノシリカやナノ 酸化チタンは, サイズ減少効果によってザラつきの 軽減や吸湿性の向上, 紫外線遮蔽能の向上といった 有用な効果が得られることから，乳液やクリーム， 日焼け止めなどの化粧品や食塩，ベーキングパウ ダー，シーズニングパウダーなどの食品に配合され る素材として古くから利用されてきた．ナノシリカ やナノ酸化チタンに代表されるナノマテリアルが化 粧品関連産業だけでも世界で年間 1000-2000トン以 上も使用されていること，また新たなナノマテリア ルが続々と開発されていることなどを鑑みると, ${ }^{2-4)}$ 今やわれわれは製造現場や環境中に廃棄されたナノ マテリアルへの非意図的な曝露や医薬品・化粧品・ 
食品を利用することによるナノマテリアルへの意図 的な曝露を避け得ない状況にある。このような中, 近年，トランスジェニックマウスなどを用いたナノ マテリアルの安全性試験の結果，カーボンナノチ ユーブがアスベスト様の発がんリスクを有するな ぞ，人類の健康を確保する上で軽視できない事実が 報告され, ${ }^{5-7)}$ ナノマテリアルは，人類にとって有 用な “光”の側面と，望ましくない“闇” の側面の 二面性を持つ素材であることが世界的に認識されつ つある. ${ }^{8,9)}$ 先述したように，ナノマテリアルへの曝 露を避け得ない現状から，世界的に，ナノマテリア ルの闇の部分のみがクローズアップされつつあり, OECD との連携のもと, 欧米各国を筆頭に，ナノ マテリアルの安全性情報が不十分なまま，ナノマテ リアルの開発や実用化を一時的に規制しようとする 動きが顕在化している。このままでは科学的根拠に 乏しいむやみな使用規制が施行されてしまい，ナノ マテリアルの光の側面を享受した豊かな社会の構築 や，ナノマテリアル産業を基盤とした産業発展が阻 害されてしまいかねない。したがって，ナノマテリ アルの安全性を科学的根拠に基づいて評価するとと もに，これらの安全性評価によって得られる情報を 基盤として安全なナノマテリアルを開発すること (NanoTox 研究)が喫緊の最重要課題となっている.

NanoTox 研究を行う上で考慮すべき点は, 医薬 品 - 化粧品 - 食品の場合, 老若男女・妊婦・胎児 乳幼児・病人を問わず，あらゆる世代のヒトが一生 涯に渡って曝露され続けることにある。そのため, ごくわずかでも吸収・蓄積され続けると, 大きな安 全性問題を招きかねない。周知の通り，どんな危険 な物質も, 曝露後, 体内に吸収されない限り安全 （化粧品の場合で言うと，経皮吸収されない限り安 全)である。すなわち, NanoTox 研究においては, ナノマテリアルが体内に吸収されるか否かを評価す ること（動態解析）が最も重要かつ最優先の検討課 題であると言っても過言ではない。しかし，NanoTox 研究の大部分は，ハザード評価（毒性の有無） に偏重しているのが現状であり, 最も肝心な体内吸 収性や体内／細胞内動態に関する情報が圧倒的に不 足している. これは, 低分子量の化学物質の場合, 一般に, 曝露と吸収がニアリイコールで捉えられて いるものの, ナノマテリアルの場合には曝露されて も吸収されない，あるいは吸収される訳がないとの
前提で，その動態解析はほとんど検討されていな い. そのため, NanoTox 研究は往々にして, 非現 実的な『実験のための実験』と批判される。このよ うな現状であるにもかかわらず，ナノマテリアルの 開発や実用化が規制されようとしていることをわれ われは強く危惧している。

そこで，われわれは，科学的根拠に基づいたナノ マテリアルの安全性確保を目指して，(1)蛍光／電顕 イメージングを活用したナノマテリアルの体内吸収 性と体内 $/$ 細胞内動態の解析, (2)既存の生化学バイ オマーカーを活用した生体影響の解析（ハザードの 特定)，(3)プロテオミクスを活用した新規安全性バ イオマーカーの探索と未知の生体影響の解析 (未知 のハザードの特定)，を融合的に推進している (Fig. 1)。これら (1)-(3)の情報の連関からナノマテ リアルの物性と安全性の因果関係を明確化すること によって, 最終的にナノマテリアルの安全性予測・ 有害性回避法の確立，さらには，有効かつ安全なナ ノマテリアル設計指針の策定につながるものと考え ている，本稿では，ナノマテリアルの中でも生産 量・使用量の点で最も汎用されている非晶質シリカ の NanoTox 研究の現状を紹介する.

\section{2. 非晶質ナノシリカの経皮吸収性及び体内動態 の評価}

非晶質シリカは，既に医薬品や化粧品，食品な ど，幅広い領域で使用されており, 10-12) 現在使用さ れているもののほとんどがナノメートルサイズの人 工合成物である。この非晶質ナノシリカは，年間 1 メガトン以上も生産され，その市場規模は 3 億 1400 万ドルにも及ぶなど, 数あるナノマテリアル の中でも使用／消費量が極めて多い素材である. ${ }^{12)}$ また従来品はアグリゲーションのため, 実際の使用 条件下ではサブミクロンサイズ以上であったが，微 小化すればするほど，使用感や透明性，吸湿性の向 上などの様々な有用機能が付与できるため, この数 年でサイズダウンや分散性の向上が加速度的に進展 しており, 現在では, 直径が $2.5 \mathrm{~nm}$ のものまで開 発されている。しかしがら，例えばわが国におい ては，従来までのサブミクロンサイズ以上のシリカ の安全性情報を基に, ナノシリカ（微粒二酸化ケイ 素) を食品中に最大 $2 \%$ まで配合することが「食品, 添加物等の規格基準（厚生省告示第 370 号）」によ

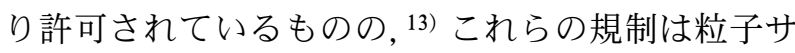




\section{Strategy of the safety assessment of Nanomaterials}

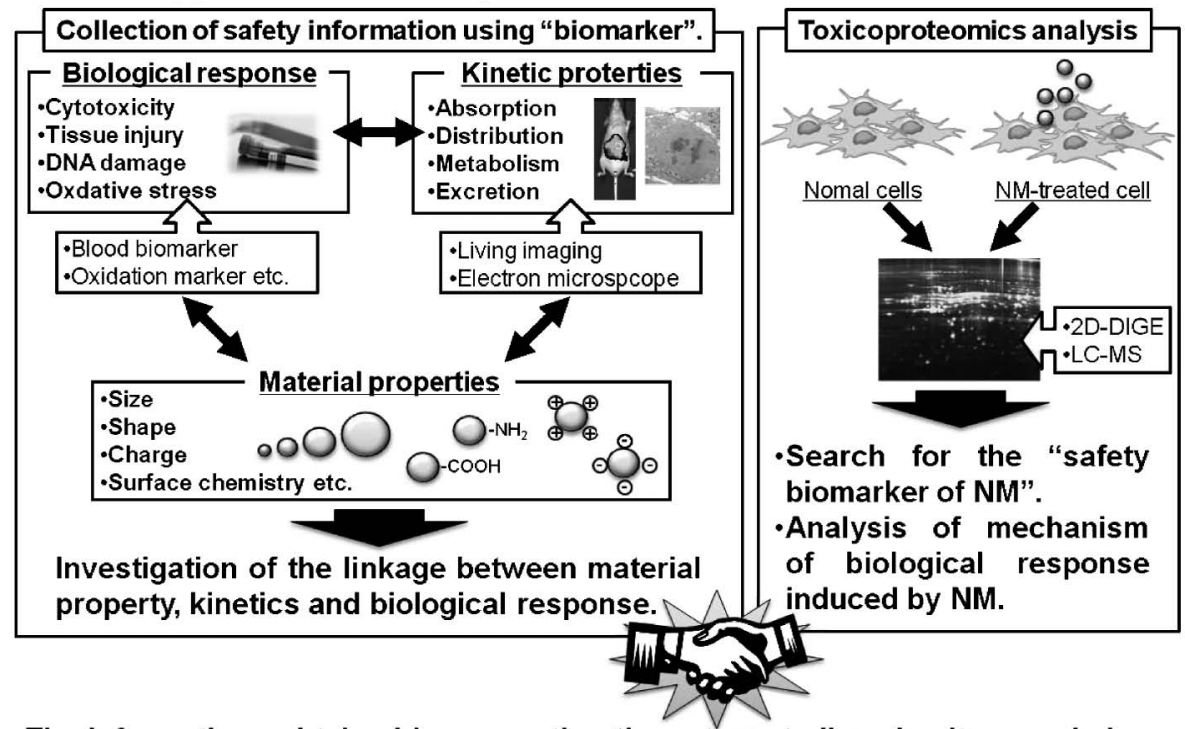

The informations obtained by promoting these two studies simultaneously have the potential to be used as "the safety biomarker; molecular, function and imaging".

Establishment of the methods to predict and avoid the hazard of NM.

Formulation of the guideline to design useful and safe NM.

Fig. 1. Scheme of Our Safety Assessment of Nanomaterials

イズにまでは言及していない。つまり，ナノメート ルサイズの非晶質シリカは適用範囲・生産量・ヒト の曝露機会が圧倒的に高い素材であるにもかかわら ず，安全性が未知のまま使用されており，数あるナ ノマテリアルの中で最も安全性評価が急がれている 素材に位置づけられる。そこで本研究では，これら の点を加味して非晶質ナノシリカの経皮吸収性／体 内・細胞内動態を評価した.

まず， 3 次元培養皮膚を用い，分散性に優れた粒 子サイズが 70, 300, $1000 \mathrm{~nm}$ の蛍光標識非晶質シリ 力（それぞれ nSP70, nSP300, mSP1000）の経皮吸 収性を評価したところ，nSP70 のみが培養皮膚の 深部にまで到達していた（未発表デー夕）。そこで 次に，マウスを用いて in vivo での経皮吸収性及び 体内／細胞内動態を透過型電子顕微鏡解析により評 価した。各シリカをマウス耳介皮膚に 3 日間及び 28 日間連続塗布し，投与局所及び所属リンパ節， 各主要組織の透過型電子顕微鏡観察を行った。 その 結果，表皮層に存在する角化細胞内（Fig. 2)， ラ ンゲルハンス細胞内，神経や血管が豊富に存在する 真皮層で nSP70 の侵入が確認された。ささらに投

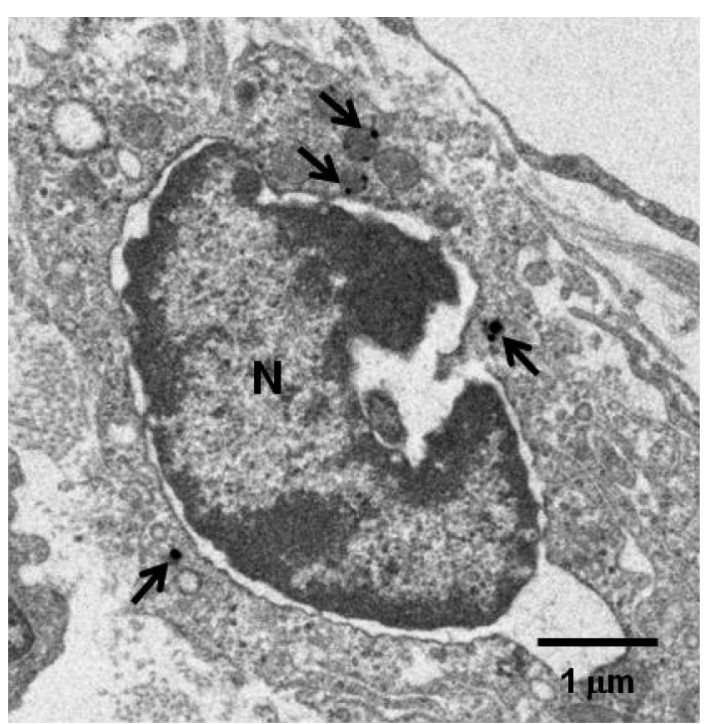

Fig. 2. TEM Observation of Skin from Dermal Administrated Mice

nSP70 suspension supplemented $(250 \mu \mathrm{g} /$ ear/day $)$ with $10 \%$ isopropyl myristate were applied to the inner side of both ears of HR-1 mice with or without 20 tape-stripping for 3 days. nSP70 were present in keratinocytes of nSP70-treated skin without tape-stripping. Arrows: nSP70, N: nucleus, Scale bars: $1 \mu \mathrm{m}$.

与部位近傍の所属リンパ節内にも nSP70 の侵入す る可能性を見い出している，以上の結果は，粒子サ 
イズが $100 \mathrm{~nm}$ 以下のナノシリカの安全性を評価す るに当たっては，経皮吸収され，全身分布する可能 性があるため，投与局所のみならず全身レベルでの 安全性評価（ハザード評価）をも実施する必要があ ることを示唆している. また $100 \mathrm{~nm}$ 以下のサイズ のナノシリカが, (1)生体中で最も強固な異物バリア として機能する皮膚をも通過する，(2)脳や免疫組織 （リンパ節や脾臓など）に蓄積するという事実は, 経皮安全性評価に加えてナノマテリアルを経肺・経 口曝露した際の安全性評価や脳神経／免疫学的な安 全性評価が必須であることを示唆している.

\section{3. 非晶質ナノシリカを全身投与した際の安全性 評価及び動態解析}

ナノシリカが全身循環した際の生体影響及び体内 ／細胞内動態を評価するために，粒子サイズが 70, 100 (nSP100), 300, $1000 \mathrm{~nm}$ のシリカを BALB/c マ ウスに尾静脈内投与 $(2 \mathrm{mg} / 匹)$ した際の急性毒性 試験を実施した。 その結果, nSP70 あるいはnSP100 を投与した群では，投与 3 時間後から立毛や体温低 下が生じ，nSP100 投与群では 40\%のマウスが死亡, nSP70 投与群においては投与後 12 時間以内にすべ てのマウスが死亡した（Table 1)。その一方で, nSP300 及び mSP1000 を投与したマウスには急性 毒性の所見を全く認めていない。ささらに，シリカ投 与 6 時間後の血液を用いて血液生化学マーカーを測 定したところ, nSP70 投与群において，肝傷害 マーカーである Alanine aminotransferase (ALT) （Table 1) 等の顕著な上昇が認められた。また，種 々肝機能マーカーが nSP70 投与群で減少する傾向 をも認めている。これらの結果は，粒子サイズが $100 \mathrm{~nm}$ 以下のナノシリカは全身分布した後に致死

Table 1. Survival Rate and Plasma ALT Activity of Mice that Injected Different Particle Size Silica Particles

\begin{tabular}{lcc}
\hline \hline Group & Survival rate $(\%)$ & $\mathrm{ALT}^{1}(\mathrm{IU} / \mathrm{l})^{2}$ \\
\hline Control & 100 & $27.6 \pm 2.13$ \\
nSP70 & 0 & $1640.4 \pm 569.6^{*}$ \\
nSP100 & 60 & $71.6 \pm 10.8$ \\
nSP300 & 100 & $35.0 \pm 2.4$ \\
mSP1000 & 100 & $32.4 \pm 2.59$ \\
\hline
\end{tabular}

Survival rate were expressed as a percentage of survival at $24 \mathrm{~h}$ after treatment of $2 \mathrm{mg} /$ head silica particles to BALB/c mice $(n=4$ or 5$)$. Plasma ALT activitiy at $6 \mathrm{~h}$ after treatment is expressed as mean \pm S.E. $(n=$ 8). . 1: Alanine aminotransferase, ${ }^{2}$ : International unit, ${ }^{*}$ Represents significant difference from the control group (Bonferoni, $p<0.01$ ).
毒性及び肝毒性が発現するリスクを孕んでいること を示すものである.

続いて，ナノシリカの肝毒性発現機序の解明を目 的に，各ナノシリカをマウス尾静脈内より投与した 際の体内動態を評価した。いずれのナノシリカを適 用した群においても，肝臟において粒子由来の蛍光 が検出され，投与後 48 時間に渡つて蛍光が観察さ れた。また，筆者らは，腸管や糞便中において粒子 由来の蛍光が検出されることを見い出しており，こ れらの情報を総合すると，血中に侵入したナノシリ カが胆汁排泄によって体外に排出されるものと予想 された．続いて，ナノシリカ投与マウスから摘出し た肝臓を用いてナノシリカの肝臓内局在を精査した。 nSP70 は肝臓全体に分布していたのに対して, $\mathrm{nSP} 300$ 及び mSP1000 投与マウスの肝臓では，胆 のうにおいてのみ蛍光が検出された。これらの結果 は，直径 $100 \mathrm{~nm}$ 以下のナノシリカがサブミクロン サイズのシリカとは異なる体内／細胞内動態特性を 発揮する可能性を示しており，ナノシリカの肝実質 細胞蓄積性や核内蓄積性を反映した生体影響解析と そのメカニズムの解明がナノシリカの安全性を確保 するに当たって必要不可欠であることが示された.

\section{4. 皮膚角化細胞株を用いた in vitroにおけるナ} ノシリカの動態・細胞応答の解析

ここまでの検討結果から，直径 $100 \mathrm{~nm}$ 以下の非 晶質ナノシリカがマイクロメートルサイズの従来素 材とは異なる動態特性を発揮し, NanoTox 研究に おいては，ナノマテリアルの動態情報を基盤とした 安全性評価が極めて重要であることを明らかにし た。そこで以降の検討では，特にナノシリカの細胞 内動態特性に焦点を当てた安全性評価について紹介 する。まず，ヒト皮膚角化細胞株（HaCaT）を用 いて, ナノシリカの細胞内局在を解析した. HaCaT 細胞に各粒子サイズのシリカを添加し，24 時間後 の細胞を透過型電子顕微鏡にて観察した。nSP300 あるいは mSP1000 を適用したいずれの群において も，細胞内に侵入した像が認められた。nSP300 添 加群ではオルガネラの形態異常などはみられなかっ たが，mSP1000を添加した群においてリソソーム 小胞の過形成を認めた。それに対して, nSP70 は 細胞内に侵入するばかりか核膜を透過して核内に侵 入していた。これらの事実は, 直径 $70 \mathrm{~nm}$ 以下の 新素材と直径 300-数 $\mu \mathrm{m}$ の従来までの素材が, 細 
胞内局在の点において全く異なる性質を発揮するこ とを裏付けるものである。したがって，非晶質ナノ シリカの安全性を確保するに当たっては，従来まで の安全性試験に加えて，遺伝子や核機能を指標とし た評価を実施する必要があると考えられた。われわ れは現在，ナノシリカの核内移行性と DNA 合成阻 害, DNA 傷害の発現機構の解明を目指して, $\mathrm{nSP70}$ 曝露細胞の核分画をサンプルとしたプロテ オーム解析を進めており (Fig. 3)，2 次元ディファ レンシャル電気泳動法を用いた解析結果から，添加 するシリカの粒子サイズの違いによって，発現量が

$\mathbf{a}$

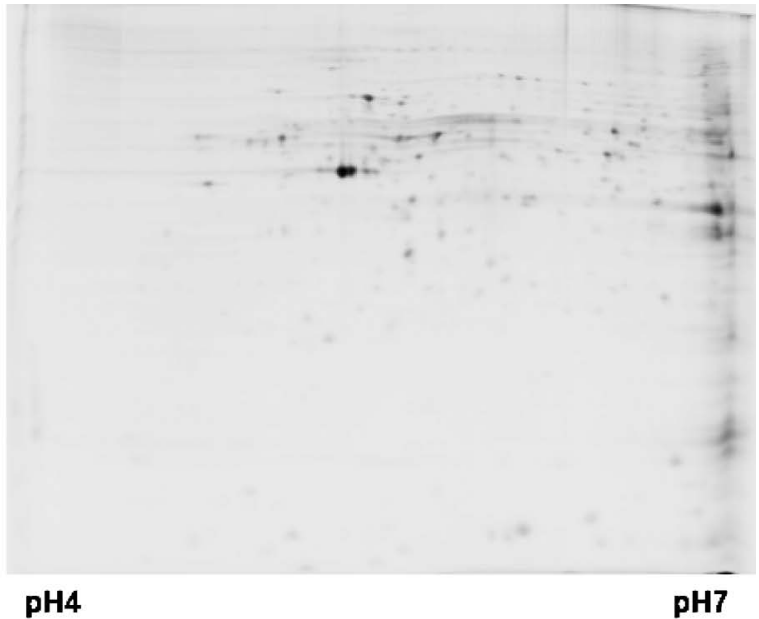

b

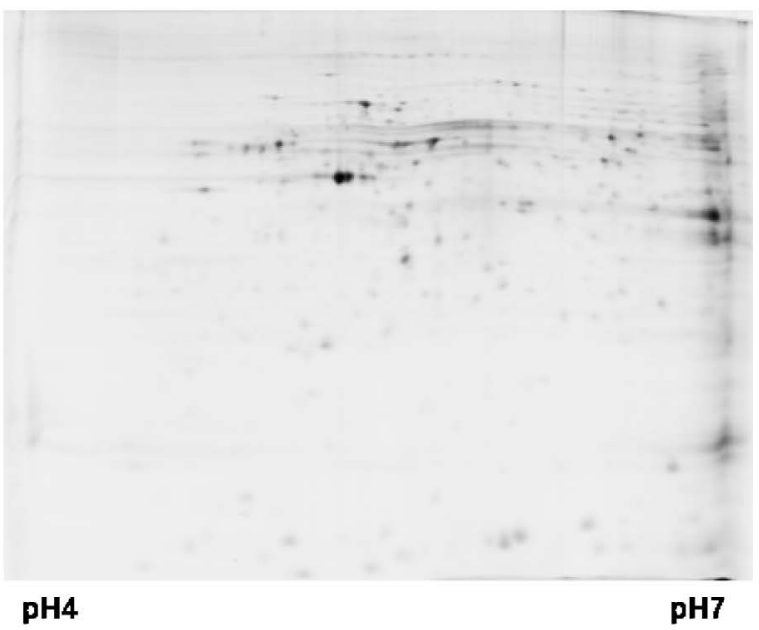

Fig. 3. 2D-DIGE Image of Fluorescently Labeled Nuclear Proteins from nSP70-treated HaCaT Cells

$\mathrm{HaCaT}$ cells were untreated or treated with nSP70 $(100 \mu \mathrm{g} / \mathrm{ml})$ for $24 \mathrm{~h}$. Proteins were labeled with Cy3 (untreated, a), Cy5 (nSP70-treated, b), and $\mathrm{Cy} 2$ (mixture of untreated and nSP70-treated as internal reference (data not shown)) and separated on pH 4-7 IPG strips in the first dimension. This procedure was followed by separation on $12.5 \%$ SDS-polyacrylamide gels in the second dimension, and the gels were scanned with a Typhoon Trio+ fluorescent scanner.
変動する多数の核内タンパク質を見い出している. これらのタンパク質は，DNA 合成阻害や DNA 傷 害の発現機序の解明に有用であることに加え，安全 性を評価できるバイオマーカーとして活用できる可 能性があることから，現在，質量分析による同定を 試みているところである．以上のナノマテリアルの 細胞内局在解析によって得られる局在部位／内部暴 露量（in vitro トキシコキネティクス）に関する情 報は，より精密なトキシコプロテオミクスを実行す る上で有用な指針を与えるものと考えている.

\section{5. おわりに}

以上，各種バイオマーカーやイメージングを活用 したトキシコキネティクス解析により，ナノメート ルサイズ（100 nm 以下）の非晶質ナノシリカが, 皮膚透過性や体内動態／生体影響の点においてサブ ミクロン以上のサイズ（数百 $\mathrm{nm}$-数十 $\mu \mathrm{m}$ ）の従来 素材とは異なる性質を発揮することを実証した。こ れらの結果は，ナノマテリアルの安全性確保・社会 受容促進を達成するためには，ナノマテリアルをマ イクロマテリアルとは別個の新素材として捉え，体 内移行性や組織浸透性／蓄積性などの動態をより慎 重に解析する必要があることを示している，過去の アスベストの例では，アスベストの利用が始まって 40-50 年で，悪性中皮腫や肺がんなどの問題が明ら かとなつた. ${ }^{14-17)}$ われわれはこれを大いに反省し, ナノマテリアルの使用が拡大しつつある今こそ，科 学的根拠に基づきつつ, ナノマテリアルの安全性対 策を講じなければならない．現在，経済開発協力機 構（OECD）が世界規模でナノマテリアルの安全性 評価ガイドラインの策定を進めており，ナノマテリ アルの開発・実用化の規制に動いているが，ナノマ テリアルが既にヒトの生活に密着していることや, ナノ産業の育成を考慮すると，慎重かつ適切な規制 が不可欠であることは言うまでもない。現在，われ われは本稿で紹介したようなナノマテリアルのサイ ズに着目した検討のみではなく，表面性状や親／疎 水バランス, 形状と, 動態や安全性との連関情報の 収集，これらの情報を基盤としたナノマテリアルの 安全性バイオマーカーの同定を推進している，将来 的には，これらの研究を基盤として科学的根拠に基 づいた安全なナノマテリアルの使用・設計指針の策 定が実現するものと期待している. 
謝辞本研究は, 厚生労働科学研究費補助金： 化学物質リスク研究事業, 文部科学省科学研究費補 助金特定領域研究 (No. 20015052), 日本学術振興会 科学研究費補助金基盤研究 B 一般 (No. 21390046), 厚生労働科学研究費補助金医薬品・医療機器等レギ ユラトリーサイエンス総合研究事業（No. H19-医 薬一一般-010), 厚生労働科学研究費補助金政策創薬 総合研究 (HS) 事業 (No. KHC1017), 厚生労働 科学研究費補助金創薬基盤推進研究事業 : 創薬バイ オマーカー探索研究事業 (No. H21-バイオー指定005), 及び財団法人永井記念薬学国際交流財団の支 援を受けて実施されたものです。ここに深謝申し上 げます，また，本総説で紹介した研究内容は，大阪 大学大学院毒性学分野 堤 康央教授（独医薬基盤 研究所創薬プロテオミクスプロジェクト プロジェ クトリーダーを併任）の統括の下，日本化粧品工業 連合会, 大阪大学大学院薬学研究科教授 八木清仁 先生，中川晋作先生，吉岡靖雄先生，医薬基盤研究 所の鎌田春彦先生, 阿部康弘先生, 長野一也先生を 始めとする多くの方々の連携によって得られた共同 成果であり，この場をお借りして御礼を申し上げま す.

\section{REFERENCES}

1) Maynard A. D., "Nanotechnology: a Research Strategy for Addressing Risk," Project on Emerging Nanotechnologies, Woodrow Wilson International Center for Scholars, 2006.

2) Nel A., Xia T., Madler L., Li N., Science, 311, 622-627 (2006).

3) European Commission, Health and Consumer Protection, Directorate General, Scientific Committee on Emerging and Newly Identified Health Risks (SCENIHR), 2005: 〈http://files. nanobio-raise.org / Downloads / scenihr.pdf $\rangle$, cited 26 January, 2010.

4) "Nanomanufacturing and the Industrial Application of Nanotechnologies, Nanoscience and Nanotechnologies: Opportunities and Uncertainties," The Royal Society \& The Royal Academy of Engineering, London, 2004, pp.
25-34.

5) Poland C. A., Duffin R., Kinloch I., Maynard A., Wallace W. A., Seaton A., Stone V., Brown S., Macnee W, Donaldson K., Nat. Nanotechnol., 3, 423-428 (2008).

6) Takagi A., Hirose A., Nishimura T., Fukumori N., Ogata A., Ohashi N., Kitajima S., Kanno J., J. Toxicol. Sci., 33, 105-116 (2008).

7) Wang J., Chen C., Liu Y., Jiao F., Li W., Lao F., Li Y., Li B., Ge C., Zhou G., Gao Y., Zhao Y., Chai Z., Toxicol. Lett., 183, 72-80 (2008).

8) Donaldson K., Stone V., Tran C. L., Kreyling W., Borm P. J., Occup. Environ. Med., 61, 727-728 (2004).

9) Oberdorster G., Oberdorster E., Oberdorster J., Environ. Health Perspect., 113, 823-839 (2005).

10) Evonik, Documents on Aerosil: $\langle\mathrm{http}: / / \mathrm{www}$. aerosil.com / aerosil / en / industries / food / default $\rangle$, cited 30 August, 2009.

11) International Risk Governance Council (IRGC), "A Report for IRGC Risk Governance of Nanotechnology Applications in Food and Cosmetics,": 〈http://www.irgc.org/IMG/pdf /IRGC_Report_FINAL_For_Web.pdf $\rangle$, cited 26 January, 2010.

12) Merget R., Bauer T., Kupper H. U., Philippou S., Bauer H. D., Breitstadt R., Bruening T., Arch. Toxicol., 75, 625-634 (2002).

13) The Japan Food Chemical Research Foundation: 〈http://www.ffcr.or.jp/zaidan/MHWinfo.nsf / a11c0985ea3cb14b492567ec002041df / 8aa11687a2aaf0c4492570650018d5ba?OpenDocument $\rangle$, cited 30 August, 2009.

14) Enterline P. E., Henderson V., Arch. Environ. Health, 27, 312-317 (1973).

15) Luo S., Liu X., Mu S., Tsai S. P., Wen C. P., Occup. Environ. Med., 60, 35-42 (2003).

16) McDonald J. C., McDonald A. D., Eur. Respir. J., 9, 1932-1942 (1996).

17) Selikoff I. J., Lilis R., Nicholson W. J., Ann. N Y Acad. Sci., 330, 295-311 (1979). 